
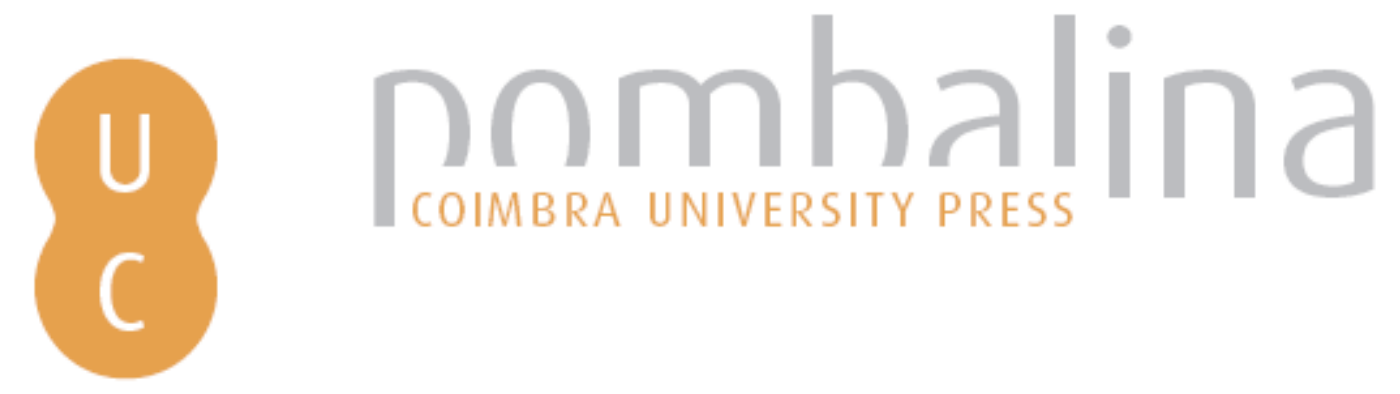

\title{
Beyond argumentativeness: the unity of argumentation
}
Autor(es):
Grácio, Rui Alexandre
Publicado por: Imprensa da Universidade de Coimbra
URL persistente:
URI:http://hdl.handle.net/10316.2/32002
DOI:
DOI:http://dx.doi.org/10.14195/978-989-26-0498-5_7
Accessed : $\quad$ 26-Apr-2023 13:44:13

A navegação consulta e descarregamento dos títulos inseridos nas Bibliotecas Digitais UC Digitalis, UC Pombalina e UC Impactum, pressupõem a aceitação plena e sem reservas dos Termos e Condições de Uso destas Bibliotecas Digitais, disponíveis em https://digitalis.uc.pt/pt-pt/termos.

Conforme exposto nos referidos Termos e Condições de Uso, o descarregamento de títulos de acesso restrito requer uma licença válida de autorização devendo o utilizador aceder ao(s) documento(s) a partir de um endereço de IP da instituição detentora da supramencionada licença.

Ao utilizador é apenas permitido o descarregamento para uso pessoal, pelo que o emprego do(s) título(s) descarregado(s) para outro fim, designadamente comercial, carece de autorização do respetivo autor ou editor da obra.

Na medida em que todas as obras da UC Digitalis se encontram protegidas pelo Código do Direito de Autor e Direitos Conexos e demais legislação aplicável, toda a cópia, parcial ou total, deste documento, nos casos em que é legalmente admitida, deverá conter ou fazer-se acompanhar por este aviso.

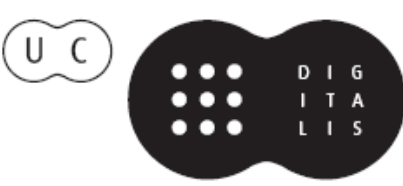




\title{
RHETORIC AND ARGUMENTATION IN THE BEGINNING OF THE XXIst CENTURY
}

\author{
EDITED BY
}

Henrique Jales Ribeiro
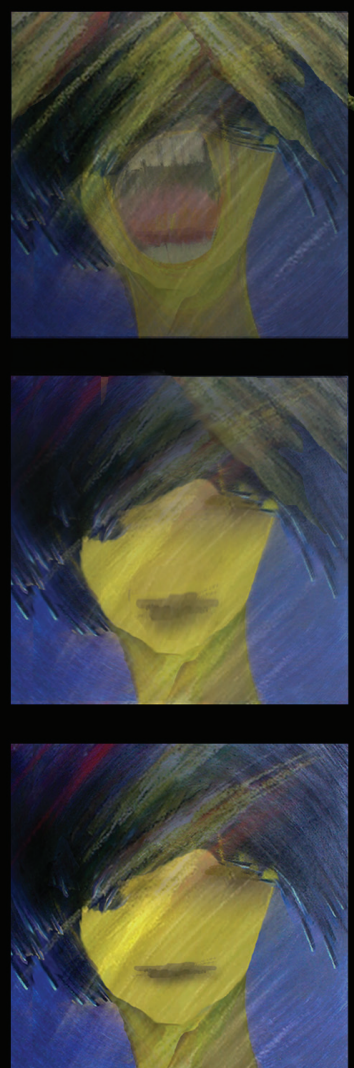
(Página deixada propositadamente em branco) 


\title{
RHETORIC AND ARGUMENTATION IN THE BEGINNING OF THE XXIst CENTURY
}

\author{
EDITED BY
}

Henrique Jales Ribeiro

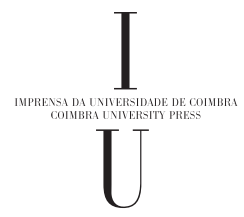

- COImbra 2009 
COORDENAÇÁO EDITORIAL

Imprensa da Universidade de Coimbra

Email: imprensauc@ci.uc.pt

URL: http://www.uc.pt/imprensa_uc

Vendas online: http://siglv.uc.pt/imprensa/

CONCEPÇÃO GRÁFICA

António Barros

CAPA

José Luís Madeira (IA / FLUC)

PRÉ-IMPRESSÁO

Paulo Oliveira

[PMP]

EXECUÇĂO GRÁFICA

Sereer, Soluçóes Editoriais

ISBN

978-989-8074-77-5

Depósito LEGAL

???????????????????????

OBRA PUBLICADA COM A COLABORAÇĀO DE:

\title{
FCT Fundação para a Ciência e a Tecnologia
}

MINISTÉRIO DA CIÊNCIA, TECNOLOGIA E ENSINO SUPERIOR Portugal

\author{
s \\ Ciência.Inovaçã̃o Programa Operacional Ciência e Inovação 2010 \\ 2010 MINISTÉRIO DA CIÊNCIA, TECNOLOGIA E ENSINO SUPERIOR \\ Unidade I\&D | Linguagem, Interpretação E Filosofia \\ ๑ JULHO 2009, IMPRENSA DA UNIVERSIDADE DE COIMBRA
}




\title{
CHAPTER 7
}

\section{BEYOND ARGUMENTATIVENESS: THE UNITY OF ARGUMENTATION}

\author{
Rui Alexandre Grácio*
}

\begin{abstract}
Although the field of argumentation has been established as an area of relevant theoretical importance with Perelman and Toulmin, the state of the art of the theories of argumentation shows that we are still in a pre-paradigmatic stage, characterized by greatly diverse and often incompatible approaches. Still, in this stage, there are signs that more than studying argumentation through the analysis of argumentativeness in a discourse with specific purposes (be it persuasion, conflict resolution, influence over others, etc.), argumentation is finally starting to be thought of as not something that results from argumentativeness, but as something that produces argumentativeness. - This change of direction is well instanced, from my point of view, when the rhetorical thematization of argumentation with its roots in the model of oratory gave way to interaction (replacing the old speaker-audience image by the arguer-arguer one). That is the orientation of those so called dialectical approaches (pragma-dialectics) and, in a much more radical way, of those that claim to be "interactionist" (Willard) or "dialogal" (Plantin) approaches. These theories focus no longer on discourse and dialogism which is inherent to it, but in the presence of interacting discourse and counter-discourse polarizing over an issue in question. Such an approach has the advantage of providing a descriptive basis to identify an argumentation if we see one. It allows us to think that it must comprehend at least three speaking turns which in pragma-dialectics theorization correspond to the first two stages of argumentation, i. e., the confrontation and opening stages. Or, as Jean Goodwin emphasizes, it allows us to understand that not every speech is an argumentation, because, in fact, it demands that something susceptible of conflict be transformed into an issue and, moreover, into an issue over
\end{abstract}

\footnotetext{
* Universidade do Minho, Instituto de Ciências Sociais, 4710-057 Braga, Portugal.

Grupo de Investigação "Ensino de Lógica e Argumentação" (LIF/FCT), da Faculdade de Letras da Universidade de Coimbra.

E-mail: rgracio@gmail.com
} 
which it is worth arguing - an "issue in question" to use my proposed terminology.-It is therefore my purpose with this paper to support the thesis according to which the unitary framework of a general argumentation theorization must focus not on a theory of the argument and a theorization of argumentativeness and its mechanisms but on a higher order of concepts such as the afore mentioned "issue in question" in which the term "in question" derives from the presence of a discourse and a counter-discourse and argumentation entails a tryout process through which the participants interact watching over and separating what is to be left to work and count as arguments, or not. As a matter of fact, that is why I define argumentation as a kind of critical reading and interacting with discourses.

I would like to begin this talk by presenting a few aspects which seem to me to characterize the present state of the study of argumentation and which at the same time I take as a diagnosis of the paths research should go along and that are pointed to in the title: "Beyond argumentativeness: the unity of argumentation".

a) One first aspect to point out is that the great diversity of contemporary theoretical perspectives on argumentation is characterized by a high rate of heterogeneity. We can even say that we are in a pre-paradigmatic stage, characterized by the emergence of multiple, often incompatible and contradicting approaches and so we cannot yet talk of a general theory of argumentation. ${ }^{1}$

b) A second aspect to be mentioned is that in almost all theorizations that come up presently, argumentation is being thought of in terms of conceptual and analytical tools that are imported from other subject fields, be it rhetoric, philosophy, language linguistics, discourse linguistics, communication, discourse analysis, logic, pragmatics or dialectics. We can't find yet an autonomous approach to argumentation, that is, one that has been built with concepts capable of establishing a descriptive field of study with a proper methodology. As it happens, for instance, the rhetorical approach explains argumentation in terms of persuasion, the linguistics approach explains argumentation on the basis of the functioning of language and discourse, the logical approach explains argumentation through criteria that point to both truth and acceptability conditions, the pragmatic and dialectical approach theorizes argumentation through the notion of reasonable critical discussion, and so forth.

c) Thirdly, although all these theories are about argumentation, they focus mainly on the kind of argumentativeness that is inherent to the use of language which supposedly results in argumentations, instead of trying to understand how argumentativeness emerges from a descriptive, conceptual and theoretical notion of argumentation.

\footnotetext{
${ }^{1}$ The same is meant by Plantin when he states that "the field of argumentation studies is not structured by such a thing as a 'paradigm'; to have a paradigm, a minimal theoretical dialogue would be required - dialogue not meaning agreement at all, but at least a way of sharing objects, methods, even problema-tics, that are not in existence for the moment. As it happens, each piece of work stands as a paradigm" (cf. Plantin 2001: 71-92). And by Eemeren when he writes that "the study of argumentation has not yet resulted in a universally accepted theory. The state of the art is characterized by the co-existence of a variety of approaches, differing considerably in conceptualization, scope and degree of theoretical refinement, albeit that all modern approaches are strongly influenced by classical and post-classical rhetoric and dialectic" (Eemeren 2003: 2).
} 
These three aspects make me believe that it is necessary to turn to a broader conceptualization that permits to theorize argumentation in an autonomous way, having in mind that the word «autonomous» implies two fundamental aspects:

a) On the one hand, we must avoid theorizing argumentation on the basis of its accommodation to pre-conceived ideals (either from an epistemic, ethic, ideological, political, didactical, philosophical, sociological, pedagogical or other order). That means to discard any kind of a priori presumption of a teleological nature in the explanation of the argumentation phenomenon. We refuse, thus, to theorize argumentation in trying to answer the question: "what is it for or what use should it have?"

b) On the other hand, it is important to try to conceptualize argumentation in a theoretical framework which resorting to distinctions, restrictions and connections, causes the emergence of concepts which can contribute to state exactly, to circumscribe and to characterize as rigorously as possible what is there to see and to show and, at the same time, to present that theoretical and conceptual construct as heuristically potent, with a broad explanatory potential and functional from a holistic point of view. In this sense, more than the study of argumentative "devices", in theorizing argumentation it is important to find a unity that permits to understand in which broader framework to ground the effective functioning of those devices.

Then, what aspects can contribute to an autonomous and general approach to argumentation?

The first issue to take into account is the descriptive basis which allows us to recognize an argumentation if we see one. To this respect, four theoretical perspectives brought important contributions: that of Charles Arthur Willard, the pragma-dialectic of van Eemeren and Rob Grootendorst, that of Jean Goodwin and the "dialogal" model of Christian Plantin.

These four perspectives share the merit of operating a shift in approaching argumentation from mono-managed discourses (taken as being "argumentations" by those who have a rhetorical perspective of argumentation and also by all the theories which start studying argumentation holding a previous theory of "argument") bringing to the forefront a certain conception of interaction. From an empirical point of view, to describe an argumentation as an interaction requires two co-oriented discourses originating in at least two arguers. That is how Willard good-humouredly applies to argumentations the saying "it takes two to tango" 2 (we will come back to this aspect later on).

To specify the kind of interaction called "argumentation" this author talks about "dissent" and "perspectivity", states that an argumentation necessary condition is opposition $^{3}$ and casts over this concept the metacommunicative assumptions he believes are inherent to any argumentation:

An argument is a social encounter built upon the following minima: I assume that we disagree, I assume that you assume we disagree; I assume that I am arguing

\footnotetext{
2 Willard 1989: 61.

3 Willard 1989: 53.
} 
and that you agree I am arguing; you assume that you are arguing and that I would agree that you are arguing. These are the metacommunicative assumptions which are independent of the subject matter at hand. ${ }^{4}$

Not very far from this line of thought stands the descriptive basis formulated by pragma-dialectics when it precedes the "argumentation stage" by the "confrontation" and "opening" stages, that is, the moment in which a conflict of opinion is revealed and the moment in which the arguers focus on the issue which causes disagreement and which will be discussed in the argumentation stage.

Jean Goodwin, on her turn, emphasizes two fundamental aspects: first, she puts the issue at the core of argumentations as something that is controversial, but adds that to reach the argumentation stage it is necessary that the issue is viewed as something worth arguing about. Thus, she writes, if, on the one hand, "an issue is a more or less determinate object of contention that is, under the circumstances, worth arguing about", on the other hand, "an issue arises when we make an issue of it"5 (notice the plural form "we").

Finally, on defining argumentation as "a kind of problematizing interaction made up of interventions arisen by a question”, ${ }^{6}$ Christian Plantin seems to be presenting the most successful synthesis for a general autonomous theorization of argumentation which deserves some attention.

First, an argumentation is described as an interaction composed of interventions (notice the plural again). According to this definition, the term "argumentation" withdraws from the mono-managed discourse that many theorists don't hesitate to consider as argumentations, an idea which, as a matter of fact, recovers Bakhtin's thesis of language dialogism. It is important to dwell for a while over this matter.

Bakhtin's idea is that "dialogue - the exchange of words - is the most natural form of language. Furthermore, fully developed utterances, even though they proceed from a single speaker - for instance, the speaker's speech, the teacher's course, the actor's monologue, the long reflections of a lonely man -, they are monological only by their external form but, by their semantic and stylistic structure, they are indeed essentially dialogical".?

We know that Perelman has thematized this dialogism in terms of audience and accordingly he emphasized the pragmatic character of communication. We also know that from this rhetorically thematized dialogism Perelman has inferred the inescapable argumentative nature of natural language.

The question to be answered is whether to affirm the dialogical and argumentative nature of language turns every discourse into an argumentation.

The words of Amossy seem to convey an affirmative sense when she states: "In so far as any word appears inside a pre-existent discursive universe, it necessarily answers interrogations that haunt contemporary thinking and are the object of both

\footnotetext{
${ }^{4}$ Willard 1989: 12.

5 Cf. Goodwin 2002: 81-96.

${ }^{6}$ Plantin 2002: 230.

7 Grize 1996: 61 .
} 
well-structured controversies and announced discussions. Any utterance confirms, refutes, problematizes preceding positions, being either expressed in a precise form by a given interlocutor or in a blurred manner in contemporary inter-discourse", ${ }^{8}$ adding subsequently "thus, argumentative analysis is connected to information released by the media as well as to the biographies of well-known men, to fictional narratives, to electoral speeches, to advertising messages, to citizenship polemics". 9

The words of Marc Angenot seem to point in the same direction when, referring to possible distinctions between rhetoric and dialectics, he writes that "any argumentation - before a crowd, in a dialogue or in petto is dialectical in this sense: it is communicative interaction, even if the public is dumb or solely virtual, that shapes and targets the uttered reasonings. Argumentation in its essence implies a constituent alterity, it institutes an enunciator and a recipient as well as a dialogical distance between the two that justifies the argumentative relation. Any arguer knows there are refutable objections, discardable counter-propositions, doubts to appease, resistances to overcome". ${ }^{10}$

These ideas call for some brief remarks. To begin with, I also agree with the idea that language is dialogical, but I think that such dialogism has only three meanings: first, it indicates that there is, to use Grize's expression, an "omnipresence of the argumentative" in the weaving of language - a fact that the theorist of natural logic expressed by saying that "to communicate one's ideas to someone is always to argue a little or a lot". ${ }^{11}$ Second, it seems to me that this "argumentative" is a determinant condition for any discourse interpretation - and in that sense it gains a fundamental hermeneutical relevance. Third, it seems to me that although a discourse's argumentativeness is critical for its interpretation, it doesn't necessarily mean that we have to see an argumentation in every discourse, that is, it is not argumentativeness which specifies an argumentation as such. What is then proper to argumentation? An argumentation is composed by speaking turns in which the perspectives conveyed by the participants' thematizations develop in accordance with interaction and whose spontaneous dynamics depends on keeping the interventions within a shared relevant zone and the constrains any of the parties can pose to the issues being discussed, causing a rupture in the argumentation.

To this respect, Amossy pertinently pointed out - recovering what according to Catherine Kerbrat-Orecchioni distinguishes interactionist pragmatics $-{ }^{12}$ that it is convenient to differentiate between real interactions (poly-managed discourses) and virtual interactions (mono-managed discourses), but she opted to keep the designation of argumentation for both: "we cannot indeed confuse face to face real interactions with virtual interactions, that are anyhow anticipated or mimed by discourse but that occur without the concrete intervention of the partner or partners. This partition is

\footnotetext{
8 Amossy 2006: 35.

9 Amossy 2006: 37.

${ }^{10}$ Angenot 2008: 51.

11 Grize 1997: 9.

12 This author writes: "rhetoric adopts a dialogical but at the same time monologal perspective while the one adopted by interactionist pragmatics is simultaneously dialogal and dialogical".
} 
important because it sets, on one part, the argumentations that must take into account the immediate reactions and answer them, adapt to the other in the stream of the conversation or debate, negotiate and co-construct meanings, and, on the other part, the argumentations that explicitly or implicitly anticipate the other's movements but that do not affront a real partner whose reactions are often unpredictable". ${ }^{13}$ But, the way I see it, the shift from argumentativeness to argumentation entails precisely this "concrete intervention from the partner or partners", even more so because, as Willard sustains, "whether or not an utterance is an argument depends on our attributions to the speaker, not to it"; ${ }^{14}$ or, quoting again the same theoretician, "it is not the presence of a particular sort of claim that makes an interaction an argument; it is the coorientation of the speakers". ${ }^{15}$ This means essentially two things: first, arguments are something that emerge from and in interaction - always under certain circumstances - and, in that case, neither the mono-managed text nor the mono-managed discourse are paradigmatic cases of argumentation, as they withdraw, on the one hand, from the interactive sway of speaking turns (of which they can occasionally represent one side) and, on the other hand, because their analysis tends to depsychologize the situated meaning that the participants intentionally assign to their statements in an interlocutionary context. ${ }^{16}$ Secondly, to determine what functions or not as an argument can not be done without inscribing it within the broader scope of the confrontation of perspectives for which the participants call forth different modes of thematizing the issues from which the actors and the interaction contexts cannot be dissociated. In other words, attention must be paid to the pragmatics of the interaction in its dialectical moves as it is a constitutive part of discourse as argumentation.

Going back to Plantin's definition, I think that when he speaks about "interventions" he means real interveners to whom in fact he assigns the roles of "proponent" and "opponent". Were we to empirically objectify the spontaneous emergence of an argumentation (that is, one which doesn't evolve in a previous institutional framework), we would say that it entails at least three speaking turns: the first bringing a perspective to the fore, the second bringing out another perspective taking into account the one previously presented and the third confirming that there is a non-coincidence in the ways of seeing the approached subject and turning it into a subject that is worth approaching as an issue - over which it is worth arguing.

On the other hand, Plantin characterizes as "problematizing" the interaction which occurs in an argumentation. The term is strikingly adequate and cautious. To

13 Amossy 2006: 218-219. This author mentions that Perelman's work is not about the shift from dialogical to dialogal but from monologal to dialogical: "Thus, the rupture accomplished by the new rhetoric doesn't concern as much the passage from the dialogical to the dialogal as it does the passage from the monological to the dialogical, from the illusion of the monologue to the dialogism inherent to any use of langage".

14 Willard 1983: 34.

15 Willard 1982: 55.

${ }^{16}$ As much as for Willard, the intention of the speaker is fundamental for us: "As a descriptive matter, we cannot know the meaning of a proposition (and of a total argument) without knowing how the speaker intended toward his utterance. We can assign meaning to his statements (as situated statements) only by confidently describing his definitions of situation. For argumentation's purposes, then, the goal of depsychologizing an argument is a profound error" (Willard 1982: 155-156). 
problematize is to question thematizations which are presented as obvious, and Perelman himself has often stated that "one doesn't argue against the obvious". ${ }^{17}$ Thus, when he chooses the term "problematize", Plantin keeps himself from conferring a priori a goal or an end to argumentations, giving just a descriptive account which tells us that empirically there is a kind of interaction in which something presented as obvious is often the object of a problematizing intervention and that, as far as normativeness and criticism apply, the issue at hand is to understand what criteria were put to work in the context of self-regulation of the argumentations themselves. That is the meaning conveyed by Marianne Doury's words when she mentions that, from an analytical point of view, "the description of norms that support common arguments is in itself one of the goals of argumentative analysis". ${ }^{18}$

Finally, this problematizing interaction which demands the intervention of at least two discourses does not unfold without a reference unit which Plantin calls "Question" (using sometimes the term "Third"). In the words of this theorist:

The confrontation of points of view causes a problem or an issue to arise which can be materialized into a question. This question is the intentional unit which organizes and defines the argumentative space. From a global standpoint, all semiotic phenomena occuring in this situation have an argumentative value. (...) The argumentative fact is a very complex thing which has as unit the global intention (the problem) which organizes the field of interchange. ${ }^{19}$

To conclude this reflection about Plantin's proposed definition and his threesome, "dialogal" model, I will quote a fragment which eloquently illustrates his concern with the question of knowing when a communicative interaction turns into an argumentation assuming, as it is, that not all communicative phenomena are argumentations:

A given language situation starts thus to become argumentative as soon as an opposition of discourse shows. Two juxtaposed, contradictory monologues without any allusion to each other, stand as an argumentative dyptic. It is, undoubtedly, the basic argumentative form: each one repeats their position. Communication is fully argumentative when this difference is problematized into a Question and the three roles of Proponent, Opponent and Third are clearly separated. ${ }^{20}$

It is, then, within the framework of this research trend which aims at an autonomous and general conceptualization of argumentation - to which the valuable contributions of Plantin concur - that I will now present a few concepts which seem to me to be of the utmost importance for a general theory of argumentation.

\footnotetext{
17 Perelman and Olbrechts-Tyteca 1988: 1.

${ }^{18}$ Doury 2004 (mise en ligne le 29 avril 2007). URL: http://semen.revues.org/document2345.html. Consulté le 29 février 2008.

19 Plantin 2003: 121-129.

${ }^{20}$ Plantin (2005: 63). It should be noticed that Plantin puts forward the idea of what turns a communicative interaction into an argumentation, that is, the question of discourse becoming argumentation.
} 
Many theoreticians would say that what argumentations are about "reason giving", "justify" points of view and, in this way, influence the other, aiming at persuasion or obtaining assent. Or else, argumentations are about finding out on which side reason stands or, still in a milder version, appealing to reasonableness. It might also be said that argumentation is a kind of critical negotiation, a way of advancing warrants for reasoning processes and strengthen them if so needed. It might also be said that what characterizes argumentation is the arguability of any conclusion, that it has to do with the linguistic constraints that the building and articulating of utterances implies or that it always seeks to solve a question.

It is my opinion that what is at stake in any argumentation are issues - and this is a first fundamental concept in a general theorization of argumentation. And it is a fundamental first concept because it embodies the distinction between form and content, which has always been problematic in the theorization of argumentation. Formally, we can say that any argumentation deals with an issue. But the concept of issue, on its turn, can only be empirically objectified in specific contents and every issue is a determined issue under certain circumstances, which means that:

a) Any issue results, on the one hand, from the non-coincidence of two perspectives leading the participants' attention to focus on that with which they disagree (in pragma-dialectics, it corresponds to the confrontation and opening stages, in Jean Goodwin's terminology, it's about turning an issue into an issue which is worth arguing about and in Plantin's words, it's about polarizing interaction in a Question).

b) Any issue results, on the other hand, from the way in which the circumstances that bring it to focus determine the direction of the interactions; that is, it's not about saying that an argumentation deals with a certain issue which is being approached in a certain context, but it's about affirming that, from the standpoint of a real argumentation, issue and context are intertwined and that the participants in an argumentation are actors that cannot be dissociated from the statutes, roles and interests which are inherent to their social practices.

Then, how are issues to be approached? Two concepts come to mind: thematization and perspectivation. In fact, the question "which procedures are required to talk about an issue?" leads to the idea that talking about an issue is being able to approach it from the standpoint of a perspective. Putting an issue under perspective - and there is no other way of talking about issues but by perspectivating them, that is, laying them out in a certain way - always corresponds to a thematization. By process of thematization I mean the particular layout of the issues, perspectivated from certain concerns which are selected in view of their relevance and whose admission directs the thought towards particular patterns of evaluation, judgement and reasoning. ${ }^{21}$ It's about a process of objectifying (not objectivity) thought, ${ }^{22}$ or, to use Grize's terminology, it's about

\footnotetext{
${ }^{21}$ In rephrasing Toulmin's notion of "field", Willard stresses the fact that if there is rationality in argumentation, it inheres precisely in the "perspective taking that makes movements in and out of fields possible” (Willard 1983: 144). In this sense, to analyse an event from an aesthetic point of view, for example, is to enter a field which demands a certain conceptual language, a set of evaluation patterns and a set of judgement models.

${ }^{22}$ In a sense very close to ours, Willard affirms that "presumption names a person's need to objectify his thinking” (Willard 1983: 144).
} 
"schematizations". Thematization is, then, the selective process of resources through which the perspective is designed and which establishes a set of points which can be used as premises for reasoning processes and their conclusions. In thematization the semantic and pragmatic dimensions operate conjointly.

Nevertheless, to focus attention on a subject through its perspectivation by means of thematization processes ${ }^{23}$ is a necessary condition to consider interaction as argumentation but not a sufficient one. At its best, it allows for the capturing of argumentativeness which is inherent to any discourse construct which makes it interpretable, as I mentioned earlier, but it does not yet allow us to talk about argumentation in the theoretically and empirically precise sense that I conferred it with. For that, it is necessary that the perspective conveyed by one of the participants on a subject be in any way challenged and put into question. In other words, it is not sufficient to take a stand at a subject, it is necessary to display that stand as a perspective which only happens - the inescapable empirical evidence - when it is confronted with another non-coincidental way of seeing it. Thus, while an argumentation is always about an issue, it doesn't objectify unless that issue is approached as "in question". That is the reason I believe that besides the concept of speaking turns, the concept of "issue in question" is the adequate unit to objectify an interaction as argumentation. We can say that the issue in question defines the relevance zone (a grey zone, in fact) in which the participants keep dwelling, because they consider that it is worth arguing about. ${ }^{24}$

Here are some of the reasons I think the notion of "issue in question" proves to be adequate to the theorization of argumentation:

- Firstly, it provides us with a descriptive basis that does not have to be subordinate to rhetoric or logic (or to any other discipline), even if the discursive strategies inherent to the uses of language and the inferences and reasoning processes evolving therein have to be considered relevant elements in considering any issue in question and in the displaying of perspectives.

- Secondly, the choice of the issue in question as a unit for reading argumentations is a way of conceptualizing that does justice to the daily usage of language and to its characteristic fluidity: it is the pattern of common use in the organization and "zone arrangement" of our daily mental schematizations. The idea of "field" (in the toulminean sense) is a good suggestion, but it is something that still remains far from that common form of language use. In any case, it's always the focalization of the issue that turns our minds to the idea of field: we identify an issue and look for resources to thematize it within a bigger circumscription which is the field (which takes us back

${ }^{23}$ In the rhetoric tradition the process of thematization is intimately connected to inventio and the relevance of inventio is particularly well instanced in the idea of "discovery" with which Aristotle undergirds his definition of rhetoric as "the ability to discover what is adequate in each case in order to persuade" (Aristóteles 1998: 48). At the same time it is rather obvious that for Aristotle rhetoric "is obviously useful and that its function is not to persuade, but to discern what are the most pertinent means to persuasion in each case" (Aristóteles 1998: 47).

${ }^{24}$ In this way, I am recovering a philosophical perspectivation of argumentation in the sense that, more than trying to explain its "functioning" from diverse standpoints, my proposed approach is about bringing forward alternative modes of organizing thought. 
to the arena of institutionalized or more or less consolidated knowledge with which we try to rhetorically sanction and strengthen our ideas).

- Thirdly, the unit "issue in question" allows for an essential shift: the one that distinguishes argumentativeness from argumentation, and leads to perceiving the former in terms of what is at stake in the latter. And what is at stake in an argumentation? From my standpoint, what is more radically at stake in an argumentation are divergent perspectivations over subjects at issue that derive from different ways of thematizing them. ${ }^{25}$ Besides, how is it possible to assume that something functions as an argument without reference to a perspective over an issue in question? And how are we to understand that it is an argumentation without taking into account that, in respect to any issue in question, we are dealing with perspectives that are divergent as far as it concerns the way of thematizing it?

I have tried to outline, albeit in a very shallow manner, some concepts that I consider to be fundamental for a general theory of argumentation. Those are the notions of "interaction", "speaking turns", "issue in question", "thematization" and "perspectivation". I will conclude with reference to what in the theory of fallacies seems relevant to me, not because I share the normative standpoint associated with such a theorization, but because it puts the emphasis on a critical aspect: it confirms the fact that focusing the issues in question and keeping interventions in their relevance zone (as mentioned before, a grey zone prone to malleability of various kinds) stands at the threshold between what unfolds as an argumentation and the voluntary deafness (resulting from an argumentative rupture) we can adopt in communication: I am referring to the fallacies usually clustered around the idea of "avoiding the issue".

The very idea of "avoiding" carries a pejorative meaning, but I would like to notice that such a negative connotation implies that argumentations have much more power than they really have, ${ }^{26}$ namely, the power to conclude and resolve consensually. That is why, from the standpoint of pragma-dialectics the closing stage is part of the process of argumentation and the ninth rule of the behaviour code of a critical discussion states that "a failed defence of a standpoint must result in the protagonist retracting the standpoint, and a successful defence of a standpoint must result in the antagonist retracting his or her doubts". ${ }^{27}$ However, in argumentations mathematics doesn't apply. Neither the perspective over an issue

25 Let it be noticed that I find the term "thematization" more adequate in the context of an holistic approach to argumentation than the term "argumentativeness", in the sense that the functionality of this latter word relates to the processes of the former.

${ }^{26}$ I share Angenot's opinion when he states that "the rational discussed world is not demonstrable but this does not exempt reasoning and reasoning with as much strength as possible, precisely because no argumentation will be decisive" (Angenot 2008: 426), and Michael A. Gilbert's observation according to which "the 'logic machine' model of argument where one partner must abandon a position when unable to respond to legitimate counter-arguments hardly ever applies. In the vast majority of situations there is more at stake, and more that must be dealt with, then the apparent claim. (...) Positions are much more complex than statements which merely serve to capsulize the web of multi-modal components that form the complex position that is really at issue" (cf. Gilbert 2000).

${ }^{27}$ Eemeren, Grootendorst and Henkemans 2002: 183. 
in question can be reduced to claims, by their turn reduced to propositional forms ${ }^{28}$ or to reasoning processes, nor resolution is really from the order of argumentation, not if we perceive as argumentation issues those that are characterized by a tryout nature open to possible concretions and not ruled by previously "teleologized" procedures consequently targetable by a battery of normative rules. I also want to emphasize that the idea of "tryout" fits well with the notion of issue given its fuzzy and malleable character and the unlimited dynamic possibilities to perspectivate, re-perspectivate, readjust the perspective, find a new perspective, and so forth. From this standpoint, it makes sense to talk about argumentation as a tryout behaviour which aims the possible concretion and it makes sense to assume that what is at stake in argumentations is to approach the issues from several standpoints and try to find a proper focalization, adjusted to each case, having in mind that this adjustment is closely linked to the specification of the relevance zone of the issue and to what may count as arguments in its thematization. I wish to point out that, according to this view, argumentation is more deeply connected to our need to have directions in our thinking, of moving through paths throughout nets of distinctions and possibilities ${ }^{29}$ - and, in this respect, the dialectical relationship with others can potentiate the process of atopia ${ }^{30}$, than to submitting discourse, utterances and propositions to evaluation criteria such as those of truth, falsity, acceptability, rationality or reasonableness. I must confess my preference for less justificationist patterns ${ }^{31}$ and more perspectivistic criteria such as perspicacity (which is a synonym for sagacity, acuteness, astuteness, artfulness, keenness, insight, subtlety) in the way of dealing with issues in interaction with other perspectives.

The closing stage combines argumentation and decision, which may lead to think that decisions can be derived from the strength of the arguments and their reasonableness. But one thing is to talk about the argumentation that sets a confrontation between perspectives and another different thing is to talk about decisions thinking that their source of legitimacy are the arguments. Only those in a position of power can decide and not anybody is in that position. Nevertheless, in societies that recognize the right to free expression of opinion, anyone can argue if one thinks it worthwhile,

\footnotetext{
${ }^{28}$ To this respect, Marc Angenot observes that "one of the misunderstandings or one of the equivoques of the normative idea of rationality is to look at it as issued from a propositional order, regulated by the true/false alternative" (Angenot 2008: 164).

29 The analogy with the path and walkers who design itineraries amongst crossroads of places, territories and people, wherein the walking makes the path and where the options are always circumstanced and interactive is indeed adequate for the theorization of argumentation and it seems to me to be heuristically more powerful than to begin such a theoretical effort taking, a contrario, a mathematized image of thought (as in Perelman's distinction between demonstration and argumentation or in Grize's question "how does thought function when it doesn't mathematize") or a juridical model (as in Perelman's idea according to which philosophers must learn with juridical practice or Toulmin's according to which logic may turn into a "generalized jurisprudence").

${ }^{30}$ In the sense Moisés de Lemos Martins ascribes to this word when he says that "atopia sets up the possibility of others places in the place that is ours and that seems exclusively so" (cf. Martins 2002: 12).

${ }^{31}$ I completely agree with Willard's thesis of the "untenability of justificational views" (cf. Willard 1989: 103-118).
} 
even if it is perfectly innocuous as far as practical effects and actual goals are concerned. On the other hand, when it comes to argumentation, there is a portion of creativity that can be triggered: one can always propose alternative interest raising points of view whereas the resolution of an argumentation always entails the recognition of a power, a source of authority which is not compatible with the possibility of alternative versions. That we call this power "reason", "truth", "reasonableness", that we appeal to "fields of knowledge" as natural sciences, law or other institutionalized knowledge or, finally, that we resort to statutes and institutional frameworks, the resolutivity of an argumentation is not a question of argumentation but a question which relates to the broader sociological dynamics throughout which discourses become rule and order and legitimate discourses. ${ }^{32}$ Because the questions of argumentation, as mentioned before, have to do with approaching issues in question, therefore open to problematization, and not with setting issues "out of question", which is what happens, one way or another, when decisions are taken about them. The accusation of "missing the issue" can simply result from a refusal to accept to consider the issues within the framework of a perspective that seems to us idle, unproductive, inconvenient or uninteresting. We can even express our incompatibility by saying to our interlocutor that "your reasoning is good, but the perspective is not so good". Or else, say in a more polite way, "I understand your point of view, but would like to consider the issue from another angle". Again, it's about plurality, perspectivism, the whole issue of optical mobility, of distance adjustment from which one wants to see and let see, which is to say, it's about situating the distinctions that count, those that are relevant to the displaying of the issue in question. To the accusation of avoiding the issue, one can still reply: "It's you that don't want to talk about the issue unless in a very restricted and simplified way, wanting to solve everything with a question, a reasoning, and an answer. You don't really want to talk about the issue, you want me to subscribe the answer in which you sum it up". Here, as it so happens with all accusations of "fallacy", applying the criterion can become a subject of debate and turn into an argument just like the others. How many questions does it take to thematize an issue? How many conclusions does it take to make an argumentation? Will there be other limits besides those linked to the inescapable urge of action and the roles we play as actors immerged in social practices?

Whatever the answers to these questions, I will say that what adds up to the enormous potential of argumentative interactions is the ability of reasonings and their conclusions, of utterances, discourses and their claims to refer back to the issues in question and the perspectives they convey through more or less explicit thematizations they are associated with. Argumentative interactions make it possible for us to situate ourselves with an increased awareness of our own limitations in problematizing and of those that are always being imposed on our possibilities of questioning and

\footnotetext{
32 Here, the question remains to be answered whether there is a concept of transcendental reason one can recur to embody the figure of the judge and which would allow for evaluating the strength and validity of the arguments from within the arguments themselves or does the strength of words always come from outside, as in Bourdieu's idea according to which "authority reaches language from the outside" (cf. Bourdieu 1982: 95).
} 
perspectivating. That is why, in fact, I define argumentation as a kind of critical reading and interaction with discourses: it means reading discourses as thematization of issues that are inherently liable to perspectivation, detection of valued focal points and generation of a counter-discourse which problematizes them. Each one will know if and what for this kind of discipline will serve. 


\section{REFERENCES}

AMOSSY, Ruth (2002), "Nouvelle rhétorique et linguistique du discours", in Roselyne Koren et Ruth Amossy (org.), Après Perelman: quelles politiques pour les nouvelles rhétoriques?, L'Harmattan. (2006), L'argumentation dans le discours, Paris: Armand Colin.

ANGENOT, Marc, 2008, Dialogues de sourds. Traité de rhétorique antilogique, Paris: Mille et une Nuits.

ARISTÓTELES (1998), Retórica, Lisboa: Imprensa Nacional Casa da Moeda.

BOURDIEU, Pierre (1982), O que falar quer dizer, Lisboa: Difel.

DOURY, Marianne (2004), "La position du chercheur en argumentation", Semen, 17: Argumentation et prise de position: pratiques discursives. URL: http://semen.revues.org/ document2345.html (mis en ligne le 29 avril 2007).

EEMEREN, Frans H. van, GROOTENDORST, Rob, and HENKEMANS, Francisca Snoek (2002), Argumentation. Analysis, Evaluation, Presentation, LEA Publishers: Londres.

EEMEREN, Frans H. van (2003), "A Glance Behind Scenes: The Sate Of the Art in the Study of Agumentation", in Studies in Communication Sciences, 3 (1).

GILBERT, Michael A. (2000), 'Agreement/Disagreement.' Proceedings of the 3rd International Conference of the Ontario Society for the Study of Argumentation, edited by Hans Hansen and Chris Tindale.

GOODWIN, Jean (2002), "Designing Issues", in Frans H. van Eemeren and Paul Houtlosser (eds.) (2002), Dialectic and Rhetoric. The Warp and Woof Argumentation Analysis, Dordrecht: Kluwer Academic Publishers, pp. 81-96.

GRIZE, J.-B. (1996), Logique naturelle and communications, Paris: P.U.F.

- (1997), Logique et langage, Paris: Éd. Ophrys.

KERBRAT-ORECCHIONI, C. (2002), "Rhétorique et interaction", in Roselyne Koren et Ruth Amossy (org.), Après Perelman: quelles politiques pour les nouvelles rhétoriques, L'Harmattan.

MARTINS, Moisés de Lemos (2002), A linguagem, a verdade e o poder, Lisboa: Fundação Calouste Gulbenkian/Fundação para a Ciência e a Tecnologia.

PERELMAN, Chaïm, et OLBRECHTS-TYTECA, Lucie (1988), Traité de l'argumentation, Bruxelles: Édition de L' Université de Bruxelles.

PLANTIN, Christian (2002), "Analyse et critique du discours argumentatif", in Roselyne Koren et Ruth Amossy (org.), Après Perelman: quelles politiques pour les nouvelles rhétoriques?, L'Harmattan.

(2001), "L'argumentation entre discours et interaction", in Lengua, discurso, texto ( $I^{\circ}$ Simposio Internacional de Análisis del Discurso), Visor Libros, pp. 71-92. (2003), "Pensar el debate", Signos, pp. 37-55, Valparaiso-Chili: Universidad Católica de Valparaiso.

(2005), L'argumentation, Paris: P.U.F..

WILlARD, Charles A. (1983), Argumentation and the Social Grounds of Knowledge, Alabama: The University of Alabama Press.

_-(1989), A Theory of Argumentation, Tuscaloosa/London: The University of Alabama Press. 
(Página deixada propositadamente em branco) 

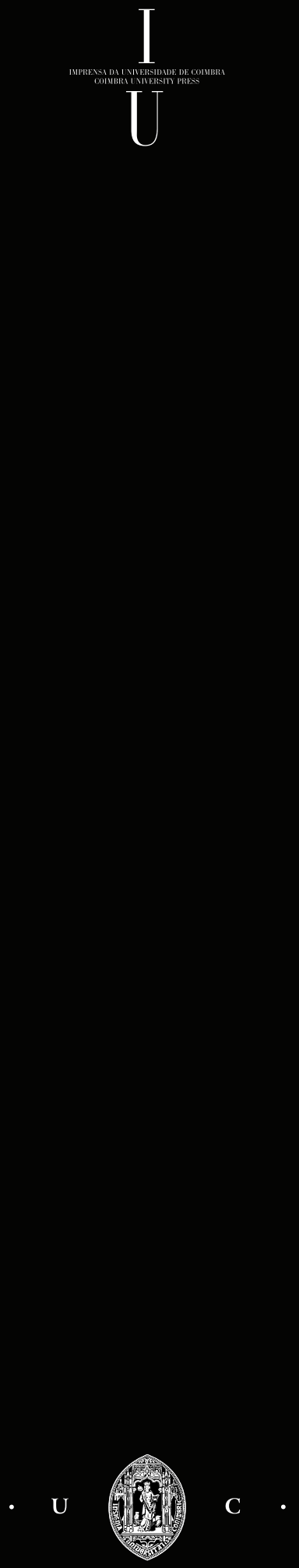